\title{
Market Integration of Major Oilseeds and Vegetable Oils in India- Evidence from Karnataka
}

\author{
Akshata Nayak ${ }^{1 *}$, Lokesha H. ${ }^{1}$ and C.P. Gracy ${ }^{2}$ \\ ${ }^{1}$ Department of Agricultural Economics, UAS, GKVK, Bengaluru, 560 065, Karnataka,India \\ ${ }^{2}$ Department of Agricultural Marketing, Co-operation, and Business Management, University of Agricultural Science, Bangalore, \\ 560065, Karnataka, India
}

"Corresponding author: akshatakn@gmail.com (ORCID ID: 0000-0002-4537-6752)

Paper No. 868

Received: 26-08-2020

Revised: 21-11-2020

Accepted: 07-12-2020

\begin{abstract}
This study has analyzed market integration across six major wholesale markets for groundnut, sunflower, and soybean. This paper investigates the market integration of selected oilseeds and respective oil markets in India by employing monthly wholesale prices from 2009 January to 2020 February. The stationarity property of the time series of prices was checked through the Augmented Dickey-Fuller (ADF) unit root test. To get the evidence in which direction the price transmission is occurring among the selected markets, Granger causality test has been used, which confirmed that some markets are influencing each other in a unidirectional way. Others have a bidirectional relationship at a five per cent level of importance, meaning that the chosen oilseed market prices have long-run association. In view of vertical integration Bellary pod market, Chennai oil and Ahmadabad oil markets are the key markets for groundnut, sunflower, and soybean, respectively. Thus, the study concluded that regional markets for selected oilseeds are strongly co-integrated. Furthermore, the study suggested that the Government can smoothen the price in most influencing markets and expect a similar result in other markets. Therefore, there is a need for faster market information movement by strengthening market intelligence by establishing an online marketing system through networking.

\section{Highlights}

( Market integration explains how distinct markets are related to one another.

0 In India, selected regional markets for selected oilseeds are strongly co-integrated.

- Strengthening of market infrastructure including transportation, storage, and communication is the need of the hour to reap the benefits of market integration.
\end{abstract}

Keywords: Markets, oilseeds, co-integration, and prices

India is one of the leading producers and consumers of vegetable oils in the world. Oilseeds have been the backbone of the agricultural economy of India for a long. Groundnut, Mustard, Soybean, and Sunflower account for a significant chunk of the output (Oilseeds Scenario in India, agropedia.iitk. ac.in). After the USA, China, and Brazil, India is the leading oilseeds producing country globally. At the global level, India contributes 19\% to oilseeds area and $2.7 \%$ to oilseeds production (FAOSTAT 2013). After cereals, oilseeds possess the prime position on the crop map of India. In 2018-19, the total oilseeds production in the nation was 31521.77 thousand tonnes in an area of about 24794.3 thousand hectares with an annual yield of $1271 \mathrm{~kg}$ per hectare. In India, the oilseeds economy has an annual turnover of around ₹ 80000 crores. It plays a vital role in the agrarian economy of the nation. In India, oilseeds occupied a significant place, following only food grains in terms of both area and production.

How to cite this article: Nayak, A., Lokesha, H. and Gracy, C.P. 2020. Market Integration of Major Oilseeds and Vegetable Oils in IndiaEvidence from Karnataka. IJAEB, 13(4): 453-460.

Source of Support: None; Conflict of Interest: None (क) $\odot$ 
Karnataka, Andhra Pradesh, Tamil Nadu, Uttar Pradesh, etc., are the country's major oilseed producing states. The vital oilseed crops in Karnataka are groundnut, sunflower, safflower, and sesamum. Karnataka is the ninth largest state in production (782.6 thousand tonnes) and the sixth largest state in area (949.21 thousand hectares) of oilseeds crops in the country, with a yield of $824 \mathrm{~kg}$ per hectare (India stat, 2018-19).

In India, the oilseeds are cultivated under rainfed conditions, which are in high-risk situation, where there will be uncertain returns on investments. A very little attention has been paid to managing production, marketing of oilseed, and price-related risks. The present scenario needs to be transformed. An emerging recognition for efficient management of risks in production and marketing of oilseed is crucial for the producers to continue producing. It is essential for producers to continue producing oilseeds. There should be prioritization of the supply chain along with risks, and identification of critical risks is vital. (Akshata et al. 2020).

Market integration is an alternative approach to stabilize prices, allocate resources, and rectify market imperfections like entrenched monopolies or monopsonies and adequate and costly information transmission. Studying price behavior helps in understanding whether spatially separated markets have price movement in tandem and converge (Gracy 2013). Market integration occurs when prices among different locations or related goods follow similar patterns over a long period. Groups of good often move proportionally to each other, and when this relationship among different markets is clear, then those markets are integrated. Thus market integration explains how different markets are related to each other when they are combined. One price in two markets indicates the degree of price transmission and the speed at which information travels between two markets. Well-integrated markets have similar prices, the dissimilarity being just the cost of transportation of the goods from one market to another.

The literature related to co-integration techniques which concern the market integration of agricultural goods in India Akshata et al. (2013); Sundaramoorthy et al. (2014); Venujayakanth et al. (2017); Sangeetha (2017) also reveals the existence of perfect market integration and price transmission are crucial for efficient management of marketing system. In an efficient marketing system, new information is confounded concurrently into markets when these markets are integrated with. This system has a considerable significance for deriving maximum gains for all the stakeholders in the system viz. producers, consumers, and middleman along the marketing chain. Considering the above issues in prospect, an attempt has been made to analyze the marketing efficiency of major oilseed markets at regional levels, with the overall objective to investigate the direction of causality among seed and oil markets.

\section{MATERIALS AND METHODS}

India as a whole was considered for the study, major oil markets of different states were selected. However, to study long-run relationship of significant oilseed crops, Karnataka State was purposively selected. Karnataka is one of the significant oilseed growing states. Karnataka is the sixth largest state in area (13.71 lakhs hectare) and production (11.21 lakhs tonnes) of oilseeds crops in the country with a yield of $833 \mathrm{~kg}$ per hectare (GOK 2016).

The present study was based on secondary data. The study was conducted for three major oilseed crops, viz., groundnut, sunflower, and Soyabean. The markets selected for the study from Karnataka were Ballary, Challakere, Tumkur_sira for groundnut seed, Bagalkot, Gadag, Koppal for sunflower seed, Bailhongal_belgum, Basavakalyana_bidar, Hubballi_dharwad for Soyabean and Chennai, Hyderabad, Mumbai, Ahmedabad, Jaipur for vegetable oils. Monthly price data for selected crops were collected from each selected regulated market for the period of Jan- 2009 to Feb- 2020 from respective APMCs as well as from the web site of NIC.

\section{Analytical of Data}

Various statistical/econometric analytical techniques, namely ADF unit root test, co-integration, Granger causality test method, were used to study the market integration.

\section{Unit Root Test}

The first stage of the analysis is to determine if the time series data is non-stationary by using the Augmented Dickey-Fuller (ADF) test. The 
appropriate lag lengths of each variable have to be resolved before the ADF test. The null hypothesis states that each time series contains a unit root that cannot be rejected for all markets at the 5\% level. Therefore, it is concluded that all-time series I (1) process and co-integration tests can now be applied.

\section{Granger causality test}

The idea of Granger causality is that if the two variables are integrated of order one, i.e., I(1), then the most accepted way to know the causal relationship between these variables is the Granger Causality proposed by Granger (1969). This study also performed Granger Causality test, which explained that the price in market $X$ causes the price in market $Y$ if and only if the past values of market $X$ provide more information for the forecast of market $Y$.

In the case of two time-series variables, say $X$ and $Y$ :

" $X$ is said to Granger-cause $Y$ if $Y$ can be better predicted using the past values of both $X$ and $Y$ than it can by using the past values of $Y$ alone."

We can test for the absence of Granger causality by estimating the following VAR model:

$Y_{t}=a_{0}+a_{1} Y_{t-1}+\ldots . .+a_{p} Y_{t-p}+b_{1} X_{t-1}+\ldots . .+b_{p} X_{t-p}+u_{t}$
$X_{t}=c_{0}+c_{1} X_{t-1}+\ldots . .+c_{p} X_{t-p}+d_{1} Y_{t-1}+\ldots . .+d_{p} Y_{t-p}+v_{t}$

Then, testing $\mathrm{H}_{0}: b_{1}=b_{2}=\ldots . .=b_{\mathrm{p}}=0$, against HA: 'Not $\mathrm{H}_{0}$ ', is a test that $X$ does not Granger-cause $Y$. Similarly, testing $\mathrm{H}_{0}: d_{1}=d_{2}=\ldots . .=d_{p}=0$, against HA: 'Not $\mathrm{H}_{0}$ ', is a test that $Y$ does not Granger-cause $X$. In each case, a rejection of the null implies there is Granger causality.

\section{RESULTS AND DISCUSSION}

The ADF test tests the null hypothesis that the time series has a unit root versus alternative no unit root. The null hypothesis of the tests is accepted or rejected based on the critical value and corresponding probability value. If the test statistics is smaller in absolute terms than the essential values and the corresponding probability value is greater than the $1 \%$ level, the series is said to be non-stationary. Table 1 depicts the outcome of the ADF test for selected oilseeds and the oil price of six significant markets for each crop at the level and their first difference. The price series in all the markets accepted the null hypothesized of having unit root at 5\% significance level at their levels and rejected the null hypotheses at the first difference, which signifies that the original series are I(1).

Table 1: ADF Tests for Unit Root in the Prices of Major oil/seed markets

\begin{tabular}{lllc}
\hline \multirow{2}{*}{ S1. No. } & \multirow{2}{*}{ Markets } & \multicolumn{2}{c}{ Augmented Dickey-Fuller (ADF) test value } \\
\cline { 2 - 3 } & Level & \multicolumn{1}{c}{$\mathbf{1}^{\text {st }}$ difference } & Critical value (1\%) \\
\hline & GROUND NUT & & -12.61174 \\
2 & BALLARY_POD & -3.078519 & -14.94678 \\
3 & CHALLAKERE_POD_ & -2.186934 & -11.34894 \\
4 & TUMKUR_SIRA_POD & -3.360310 & -11.05694 \\
5 & CHENNAI_OIL & -2.032727 & -10.14485 \\
6 & HYDERABAD_OIL & -2.628623 & -12.17502 \\
\hline & MUMBAI_OIL & -2.287107 & \\
\hline 1 & SUNFLOWER & & 18.13809 \\
2 & BAGALKOT_SEED & 2.524694 & 12.09165 \\
3 & GADAG_SEED & 3.037553 & 16.98406 \\
4 & KOPPAL_SEED & 2.747999 & 12.57507 \\
5 & CHENNAI_OIL & 1.889792 & 12.35207 \\
6 & HYDERABAD_OIL & 2.089583 & -3.480425 \\
\hline & MUMBAI_OIL & 3.871069 & 15.02536 \\
\hline 1 & SOYABEAN & & \\
2 & BAILHONGAL_BELGUM_SEED & 2.486536 & 12.29189 \\
3 & BASAVAKALYANA_BIDAR_SEED & 2.544091 & 14.45231 \\
4 & HUBBALLI_DHARWAD_SEED & 2.957253 & 11.34827 \\
5 & AHMEDABAD_GUJARATH_OIL & 2.610143 & 12.20363 \\
6 & JAIPUR_OIL & 1.415585 & 11.29076 \\
\hline
\end{tabular}


The technique of Engle and Granger bivariate cointegration was also tested for the presence of long-run relationship existing between seed/ pod and oil price in different states. The causal relationship among the major selected in India was approached through Grangers Causality technique. The test for causality is based on F statistics. Table 2 , 3, and 4 depict the Causality result. It could be seen the existence of both unidirectional as well as the bidirectional relationship among the selected oilseed/oil markets. Thus the study observed that a strong integration of major selected oilseed/ oil markets in India shows that the price of one market influence the price of other markets. The results presented in Fig. 1 explicates that the few groundnut market pairs such as Challakere_podChennai_oil market and Chennai_oil-Mumbai_oil markets have bidirectional causality. In these cases, the former market in every pair granger causes the price formation in the other market, which in turn provides a signal to the former market as well. The rest of the market pairs have unidirectional causality. It means that a price change in the former market in each pair influences the price formation in the latter market, but the price change in the latter market is not influencing the price change in the former market. Ballary_pod markets granger causes the price formations in the rest of the markets, whereas a Hyderabad_oil and Tumkur_pod market does not influence price formation in any of the markets. And also, Challakere_pod market granger causes the price formations in Hyderabad_oil and Tumkur_ pod. And also, the unidirectional relationship was found for the pair of Mumbai_oil- Hyderabad_oil, Chennai_oil-Tumkur_pod, Hyderabad_oil market.

Fig. 2 will visualize the unidirectional causalities among the selected sunflower market pairs: Chennai_oil-Hyderabad_oil, Chennai_oil-Koppal seed, Chennai_oil-Bagalkot seed, Chennai_oilGadag seed, Mumbai_oil-Chennai_oil, Mumbai_

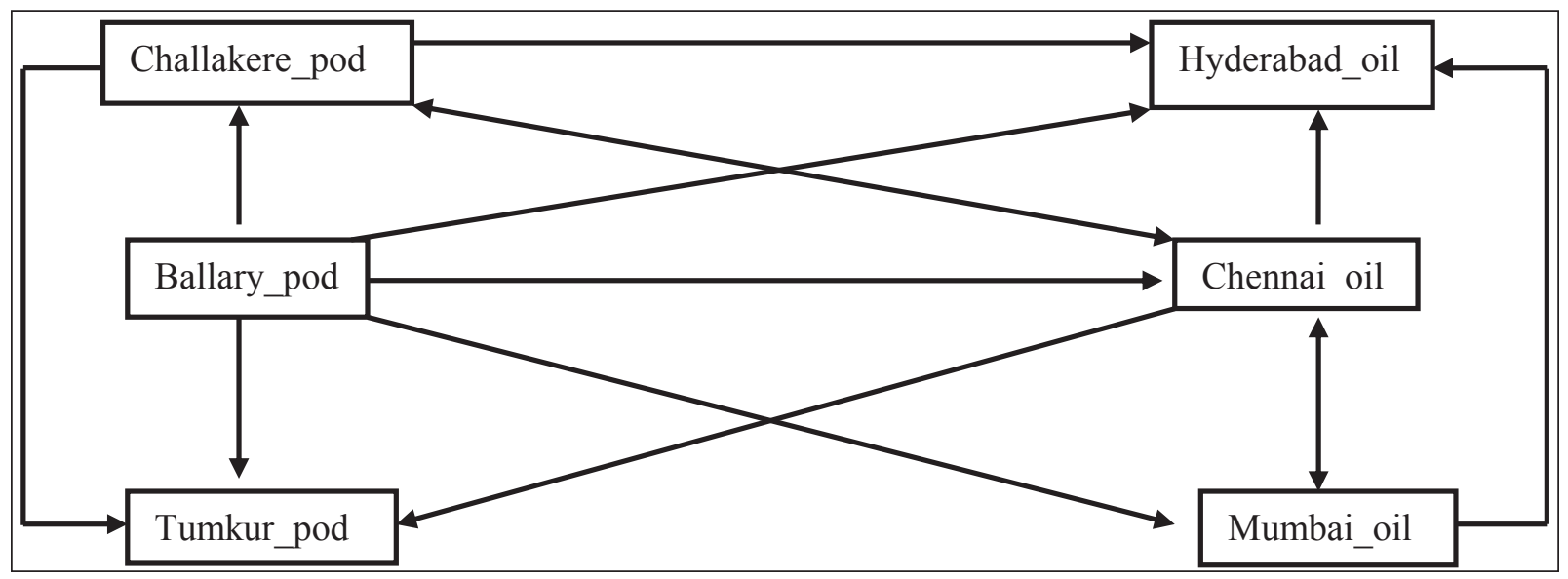

Fig. 1: Causal relationship among major groundnut pod to oil markets under study

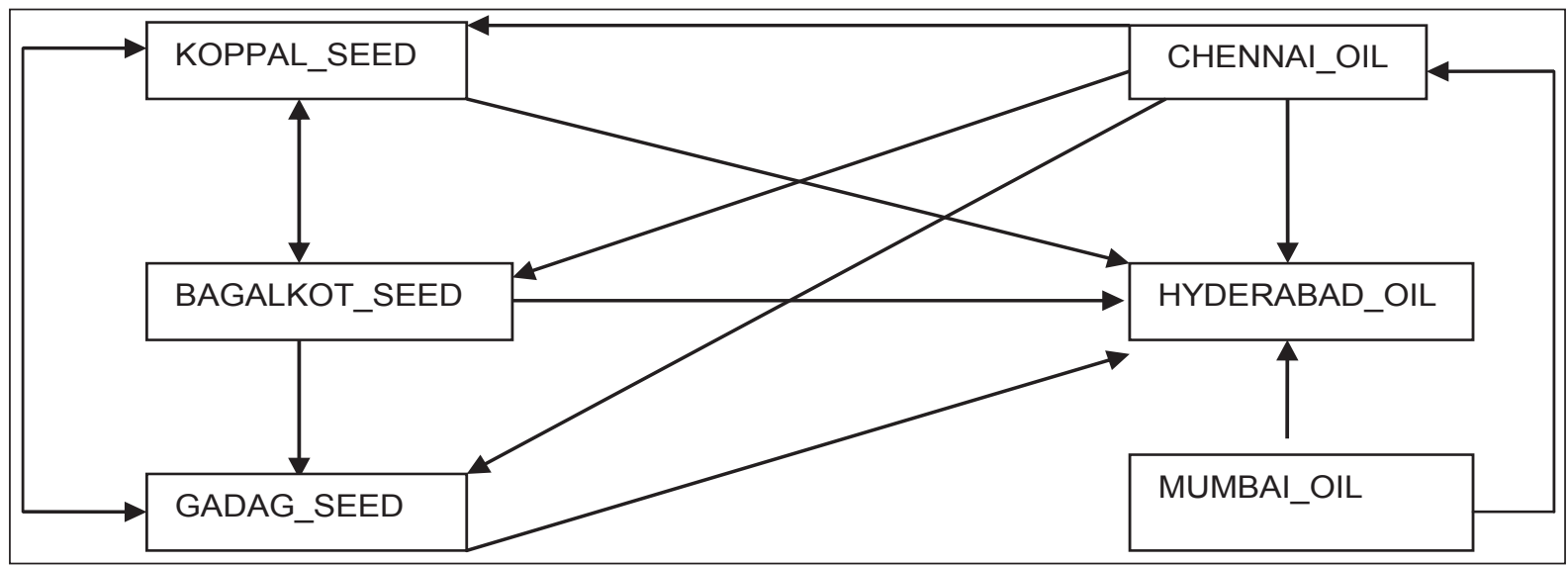

Fig. 2: Causal relationship among major sunflower seed to oil markets under study 
Table 2: Granger causality test for different groundnut oil and pod markets in India

\begin{tabular}{|c|c|c|c|}
\hline Null Hypothesis & F-Statistic & Prob. & Reject $\mathrm{H}_{0}$ \\
\hline CHALLAKERE_POD_does not Granger Cause BALLARY_POD_ & 2.17615 & 0.1177 & Accept \\
\hline BALLARY_POD_does not Granger Cause CHALLAKERE_POD_ & 10.7851 & $5.00 \mathrm{E}-05$ & Reject \\
\hline CHENNAI_OIL_does not Granger Cause BALLARY_POD_ & 2.26222 & 0.1083 & Accept \\
\hline BALLARY_POD_does not Granger Cause CHENNAI_OIL_ & 3.56144 & 0.0313 & Reject \\
\hline HYDERABAD_OIL_does not Granger Cause BALLARY_POD_ & 0.10671 & 0.8989 & Accept \\
\hline BALLARY_POD_does not Granger Cause HYDERABAD_OIL_ & 6.02648 & 0.0032 & Reject \\
\hline MUMBAI_OIL_does not Granger Cause BALLARY_POD_ & 2.56025 & 0.0813 & Accept \\
\hline BALLARY_POD_does not Granger Cause MUMBAI_OIL_ & 3.90491 & 0.0226 & Reject \\
\hline TUMKUR_SIRA_POD_does not Granger Cause BALLARY_POD_ & 2.34064 & 0.1004 & Accept \\
\hline BALLARY_POD_does not Granger Cause TUMKUR_SIRA_POD_ & 17.8974 & $1.00 \mathrm{E}-07$ & Reject \\
\hline CHENNAI_OIL_does not Granger Cause CHALLAKERE_POD_ & 4.13104 & 0.0183 & Reject \\
\hline CHALLAKERE_POD_does not Granger Cause CHENNAI_OIL_ & 3.61599 & 0.0297 & Reject \\
\hline HYDERABAD_OIL_does not Granger Cause CHALLAKERE_POD_ & 0.38782 & 0.6793 & Accept \\
\hline CHALLAKERE_POD_does not Granger Cause HYDERABAD_OIL_ & 3.33748 & 0.0387 & Reject \\
\hline MUMBAI_OIL_does not Granger Cause CHALLAKERE_POD_ & 0.6128 & 0.5434 & Accept \\
\hline CHALLAKERE_POD_does not Granger Cause MUMBAI_OIL_ & 1.3114 & 0.2731 & Accept \\
\hline TUMKUR_SIRA_POD_does not Granger Cause CHALLAKERE_POD_ & 0.1938 & 0.8241 & Accept \\
\hline CHALLAKERE_POD_does not Granger Cause TUMKUR_SIRA_POD_ & 25.8824 & $4.00 \mathrm{E}-10$ & Reject \\
\hline HYDERABAD_OIL_does not Granger Cause CHENNAI_OIL_ & 0.26513 & 0.7675 & Accept \\
\hline CHENNAI_OIL_does not Granger Cause HYDERABAD_OIL_ & 8.40842 & 0.0004 & Reject \\
\hline MUMBAI_OIL_does not Granger Cause CHENNAI_OIL_ & 10.92 & 4.00E-05 & Reject \\
\hline CHENNAI_OIL_does not Granger Cause MUMBAI_OIL_ & 3.12952 & 0.0471 & Reject \\
\hline TUMKUR_SIRA_POD_does not Granger Cause CHENNAI_OIL_ & 0.43639 & 0.6473 & Accept \\
\hline CHENNAI_OIL_does not Granger Cause TUMKUR_SIRA_POD_ & 8.71846 & 0.0003 & Reject \\
\hline MUMBAI_OIL_does not Granger Cause HYDERABAD_OIL_ & 5.54297 & 0.0049 & Reject \\
\hline HYDERABAD_OIL_does not Granger Cause MUMBAI_OIL_ & 1.32749 & 0.2688 & Accept \\
\hline TUMKUR_SIRA_POD_does not Granger Cause HYDERABAD_OIL_ & 2.89891 & 0.0587 & Accept \\
\hline HYDERABAD_OIL_does not Granger Cause TUMKUR_SIRA_POD_ & 2.01511 & 0.1375 & Accept \\
\hline TUMKUR_SIRA_POD_does not Granger Cause MUMBAI_OIL_ & 2.45709 & 0.0897 & Accept \\
\hline MUMBAI_OIL_does not Granger Cause TUMKUR_SIRA_POD_ & 2.89018 & 0.0592 & Accept \\
\hline
\end{tabular}

Table 3: Granger causality test for different sunflower oil and seed markets in India

\begin{tabular}{llll}
\hline Null Hypothesis & F-Statistic & Prob. & Reject Ho \\
\hline CHENNAI_OIL_does not Granger Cause BAGALKOT_SEED_ & 4.81157 & 0.0097 & Reject \\
BAGALKOT_SEED_does not Granger Cause CHENNAI_OIL_ & 0.88175 & 0.4166 & Accept \\
GADAG_SEED_does not Granger Cause BAGALKOT_SEED_ & 0.73447 & 0.4818 & Accept \\
BAGALKOT_SEED_does not Granger Cause GADAG_SEED_ & 6.85232 & 0.0015 & Reject \\
HYDERABAD_OIL_does not Granger Cause BAGALKOT_SEED_ & 0.29902 & 0.7421 & Accept \\
BAGALKOT_SEED_does not Granger Cause HYDERABAD_OIL_ & 7.13433 & 0.0012 & Reject \\
KOPPAL_SEED_does not Granger Cause BAGALKOT_SEED_ & 4.61388 & 0.0116 & Reject \\
BAGALKOT_SEED_does not Granger Cause KOPPAL_SEED_ & 15.3234 & $1.00 \mathrm{E}-06$ & Reject \\
MUMBAI_OIL_does not Granger Cause BAGALKOT_SEED_- & 0.78275 & 0.4593 & Accept \\
BAGALKOT_SEED_does not Granger Cause MUMBAI_OIL_ & 0.35468 & 0.7021 & Accept \\
GADAG_SEED_does not Granger Cause CHENNAI_OIL_ & 0.35452 & 0.7022 & Accept \\
CHENNAI_OIL_does not Granger Cause GADAG_SEED_ & 6.62663 & 0.0018 & Reject \\
HYDERABAD_OIL_does not Granger Cause CHENNAI_OIL_ & 1.15968 & 0.3169 & Accept \\
CHENNAI_OIL_does not Granger Cause HYDERABAD_OIL_ & 3.73693 & 0.0265 & Reject \\
KOPPAL_SEED_does not Granger Cause CHENNAI_OIL_ & 0.80886 & 0.4476 & Accept \\
CHENNAI_OIL_does not Granger Cause KOPPAL_SEED_ & 8.52794 & 0.0003 & Reject
\end{tabular}


MUMBAI_OIL_does not Granger Cause CHENNAI_OIL_ CHENNAI_OIL_does not Granger Cause MUMBAI_OIL_ HYDERABAD_OIL_does not Granger Cause GADAG_SEED_ GADAG_SEED_does not Granger Cause HYDERABAD_OIL_ KOPPAL_SEED_does not Granger Cause GADAG_SEED_ GADAG_SEED_does not Granger Cause KOPPAL_SEED_ MUMBAI_OIL_does not Granger Cause GADAG_SEED_ GADAG_SEED_does not Granger Cause MUMBAI_OIL_ KOPPAL_SEED_does not Granger Cause HYDERABAD_OIL_ HYDERABAD_OIL_does not Granger Cause KOPPAL_SEED_ MUMBAI_OIL_does not Granger Cause HYDERABAD_OIL_ HYDERABAD_OIL_does not Granger Cause MUMBAI_OIL_ MUMBAI_OIL_does not Granger Cause KOPPAL_SEED_ KOPPAL_SEED_does not Granger Cause MUMBAI_OIL_

$\begin{array}{lll}6.34896 & 0.0024 & \text { Reject } \\ 0.41358 & 0.6622 & \text { Accept } \\ 0.39135 & 0.677 & \text { Accept } \\ 6.1049 & 0.0029 & \text { Reject } \\ 6.07615 & 0.003 & \text { Reject } \\ 3.31473 & 0.0395 & \text { Reject } \\ 1.94143 & 0.1477 & \text { Accept } \\ 0.64777 & 0.5249 & \text { Accept } \\ 5.04914 & 0.0078 & \text { Reject } \\ 2.27994 & 0.1065 & \text { Accept } \\ 5.89891 & 0.0036 & \text { Reject } \\ 0.46347 & 0.6302 & \text { Accept } \\ 2.39002 & 0.0957 & \text { Accept } \\ 0.36212 & 0.6969 & \text { Accept }\end{array}$

Table 4: Granger causality test for different soya bean oil and seed markets in India 


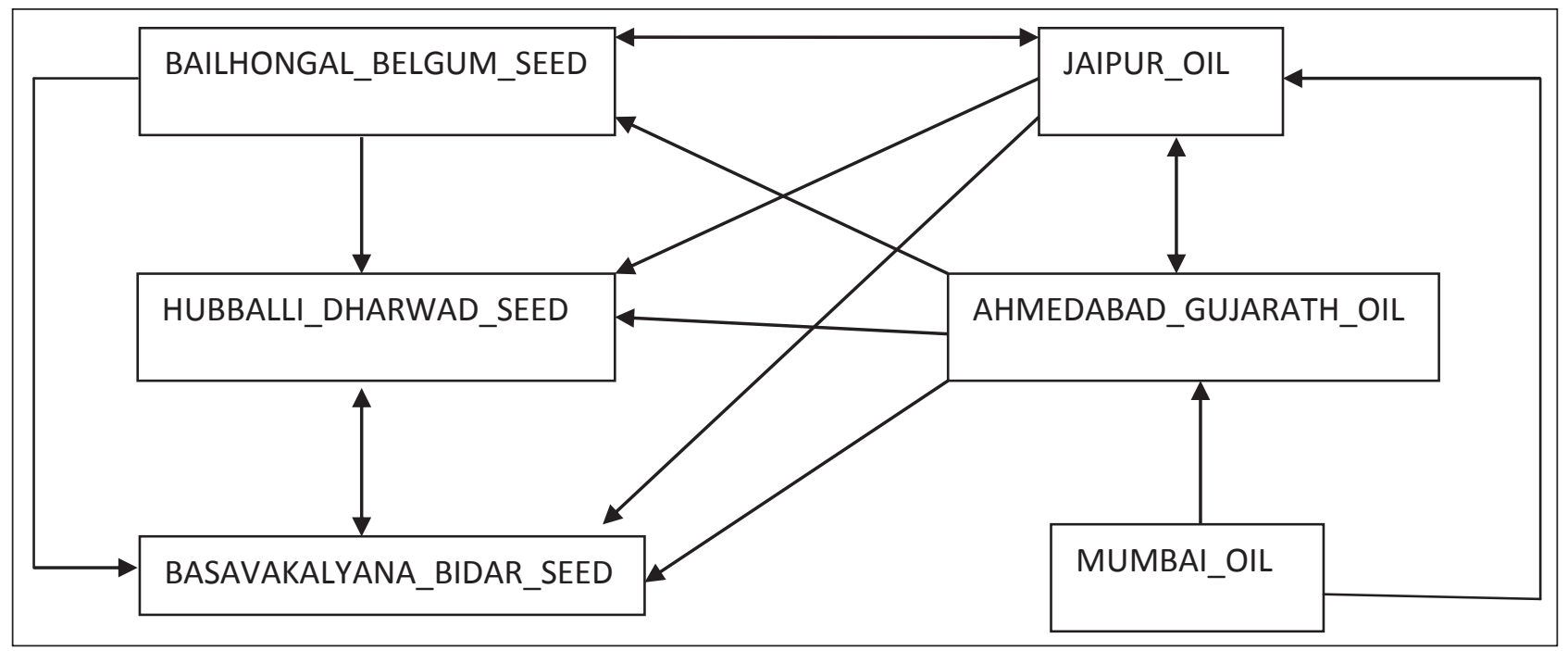

Fig. 3: Causal relationship among major soya bean seed to oil markets under study

oil- Hyderabad_oil, Koppal seed-Hyderabad_ oil, Bagalkot seed-Hyderabad_oil, Gadag seedHyderabad_oil, and Bagalkot seed-Gadag seed markets, represents that a price change in the former market in each pair granger causes/influence the price formation in the other market. There is bidirectional causality between Koppal seed marketBagalkot seed market and the Gadag seed -Koppal seed markets. In these cases, the former market in each pair granger causes the price formation in the other market, which in turn gives the feedback to the former market as well. Further, there is no casuality between Mumbai_oil to selected sunflower seed markets, indicating that neither Mumbai_oil market granger causes the price formation in selected sunflower seed markets nor the selected sunflower seed markets granger causes the price formation in Mumbai_oil markets. In other words, there is no long-run price association between these market pairs

From Fig. 3 it is identified that there is bidirectional causality between Bailhongal- Jaipur, HubballiBasavakalyana, and also between Jaipur- Ahmedabad markets. In these cases, the former market in each pair granger causes the price formation in the other market, which in turn gives the feedback to the former market as well. Similarly, unidirectional causality was found between Jaipur-Hubballi, Jaipur-Basavakalyana, Ahmedabad- Bailhongal, Ahmedabad- Hubballi, Ahmedabad- Basavakalyana, Mumbai- Jaipur, Mumbai- Ahmedabad, BailhongalHubballi, and Bailhongal- Basavakalyana markets shows that a price change in the former market in each pair granger causes/influences the price formation in the latter market, but the price change in the latter market is not influencing price change in the former market in each pair. Overall, the selected soyabean markets seem to be integrated with each other to a fair extent.

\section{CONCLUSION}

The study investigates the stationarity and cointegration in major groundnut, sunflower, and soybean markets of India. The study examines the market integration in six selected markets for each selected crop using Granger causality test. Unit root test shows that the price series in each market are non-stationary at their levels, and it becomes stationary after the first differences. The out of granger causality shows that the direction of price changes between two selected markets. According to the outcome of the granger causality test, the study found both unidirectional and bidirectional causalities between all 3 selected oilseed crop market pairs. The results of causality in groundnut markets confirmed that the few groundnut market pairs, such as Challakere_podChennai_oil market and Chennai_oil-Mumbai_oil markets, have bidirectional causality. Ballary_pod markets Granger cause the price formations in the rest of the markets, whereas Hyderabad_oil and Tumkur_pod markets do not granger cause price formation in any of the markets. And also, Challakere_pod market granger causes the price formations in Hyderabad_oil and Tumkur_pod. And again, the unidirectional relationship was 
found for the pair of Mumbai_oil- Hyderabad_oil, Chennai_oil-Tumkur_pod, Hyderabad_oil market. In the case of sunflower market pairs, unidirectional causalities found between Chennai_oil-Hyderabad_ oil, Chennai_oil-Koppal seed, Chennai_oil-Bagalkot seed, Chennai_oil-Gadag seed, Mumbai_oilChennai_oil, Mumbai_oil-Hyderabad_oil, Koppal seed-Hyderabad_oil, Bagalkot seed-Hyderabad_oil, Gadag seed-Hyderabad_oil, and Bagalkot seedGadag seed markets, and there is bidirectional causality between Koppal seed market-Bagalkot seed market and Gadag seed-Koppal seed markets. Further, there is no casuality between Mumbai_oil to selected sunflower seed markets. In the case of soyabean bi-direction causality between BailhongalJaipur, Hubballi-Basavakalyana, and JaipurAhmedabad markets.

Similarly, a unidirectional relationship was found between Jaipur-Hubballi, Jaipur-Basavakalyana, Ahmedabad-Bailhongal, Ahmedabad-Hubballi, Ahmedabad-Basavakalyana, Mumbai-Jaipur, Mumbai- Ahmedabad, Bailhongal- Hubballi, and Bailhongal- Basavakalyana markets. Overall, the study concluded that selected oilseed markets in India are strongly co-integrated. Therefore, the Government can stabilize the price in one key market and expect a similar result in other markets. This helps to reduce the cost of stabilization considerably. The suggested policy intervention calls for faster movement of market information through strengthening market intelligence along with the establishment of an online marketing system through networking. Development/strengthening of market infrastructure, including communication, transportation, and storage facilities, are the need of the hour to integrate the market prices fully.

\section{REFERENCES}

Akshata, N., Gracy, C.P., Nagashree, N. and Jyoti, N. 2013. Growth of sunflower production in India - a comparative analysis, Mysore J. Agril. Sci., 47(3): 628-634.

Government of India. 2016. Agricultural statistics at a glance 2016. Department of Agriculture and Co-operation. Ministry of Agriculture and Farmers Welfare, New Delhi, pp. 118-119.

Government of Karnataka. 2013. Estimates of principal crops in Karnataka for the year 2012-2013. Annual Report 201213. Directorate of Economics and Statistics. Bangalore.

Gracy, C.P., Akshata, N., Nagashree, N. and Girisha, K. 2013. Sunflower market cointegration analysis - a market intelligence tool for marketing decisions. Mysore J. Agril. Sci., 47(4): 835-839.

Nayak, A., Lokesha, H. and Gracy, C.P. 2020. Co-integration of Groundnut Markets in India with Special Reference to Karnataka State, Cur. J. Appl. Sci. Tech., 39(18): 14-22.

Sangeetha, R., Ramanand, M.S. and Menaka, S. 2017. An Econometric Analysis on Groundnut Markets in India, Int. J. Cur. Microb. Appl. Sci., 6(8): 2131-2142.

Sundaramoorthy, C., Girish, K.J., Suresh Pal and Mathur, V.C. 2014. Market integration and volatility in edible oil sector in India, J. Indian Soc. Agril. Statis., 68(1): 67-76.

Venujayakanth, B., Dudhat, A.S., Swaminathan, B. and Ardeshana, N.J. 2017. Price Integration Analysis of Major Groundnut Domestic Markets in India, Economic Affairs, 62(2): 233-241.

Viswanatha Reddy, K. and Kingsly Immanuelraj. 2017. Area, production, yield trends and pattern of oilseeds growth in India, Economic Affairs, 62(2): 327-334.

www.gktoday.in

http://www.indiastat.com/

www.faostat.com 